\section{Postharvest Performance of Selected Colombian Cut Flowers after Three Transport Systems to the United States}

\author{
Ria T. Leonard ${ }^{1}$, Amy M. Alexander, and Terril A. Nell
}

AdDitional INDEX wORDs. Alstroemeria peruviana, Dianthus caryophyllus, Gerbera jamesonii, Rosa bybrida, temperature, vase life

SUMMARY. This study examined three transport systems used to transport fresh, nonstored cut flowers from Bogotá, Colombia, to the United States on a monthly basis for 1 year. Five cultivars of cut rose (Rosa bybrida), alstroemeria (Alstroemeria peruviana), carnation (Dianthus caryophyllus), and gerbera (Gerbera jamesonii) were commercially transported using a 7-day conventional distribution system with temperature controls and two rapid transport systems (3-day or 24-hour) with little or no temperature controls, respectively. Temperatures during the 24-hour transport system increased steadily and temperatures were at or above $10{ }^{\circ} \mathrm{C}$ for $\approx 18 \mathrm{~h}$, with half of that time above $15{ }^{\circ} \mathrm{C}$ for all shipments. The 3 - and 7 -day systems had temperature fluctuations ranging from 3 to $24^{\circ} \mathrm{C}$ and 3 to $19^{\circ} \mathrm{C}$, respectively. Flowers transported using the rapid transport systems had a significantly longer vase life compared with the 7 -day transport in $83 \%$ of the shipments of alstroemeria and roses, in $58 \%$ of the shipments of carnations, and in $50 \%$ of the shipments of gerberas. Vase life increased $5.6 \%$ to $17.1 \%$ ( 0.7 to 2.1 days) for roses, $3.2 \%$ to $16.7 \%$ ( 0.5 to 2.7 days) for alstroemerias, $12.8 \%$ to $34.6 \%$ ( 1.1 to 6.2 days) for gerberas, and $4.6 \%$ to $8.8 \%$ ( 1.1 to 2.3 days) for carnations when using the rapid transport systems compared with the 7-day transport system. Some cultivars were more tolerant of the longer transport. The results show that when using fresh, non-stored flowers, the rapid transport systems had equal or longer vase life than the 7-day transport system in the majority of shipments for each flower species. Results also demonstrate that better temperature management during transport is a critical issue in the floral industry that needs to be improved upon.

$\mathrm{T}$ he majority of fresh cut flowers sold in the United States are produced abroad, primarily in Central and South American countries (Jerardo, 2007). It generally takes 5 to $7 \mathrm{~d}$ or longer, to commercially distribute these flowers to consumers throughout the United States via air and truck transport (Nell and Leonard, 2005). Presently, there is considerable emphasis and discussion within the floral industry regarding the lack

Department of Environmental Horticulture, P.O. Box 110670, University of Florida, Gainesville, FL 32611

This research was funded by FedEx Corp. who coordinated flower shipments but played no role in study design, or in the collection, analysis, and interpretation of data or writing of paper.

We gratefully acknowledge James Colee at the Department of Statistics, University of Florida, for statistical assistance, Dr. David Clark and Dr. Jianjun Chen for reviewing the manuscript, and Dianne Amendola, Camila Paula, and Mittu Pannala for laboratory assistance. We also thank Chrysal, Miami, FL, for supplying floral products and Syndicate Sales for the supply of vases.

Mention of proprietary products or companies does not imply endorsement by the authors or the University of Florida or its approval to the exclusion of other suitable products or companies.

${ }^{1}$ Corresponding author. E-mail: rleonard@ufl.edu. of cold temperature management (cold-chain) during flower transport (Reid and Jiang, 2005; Staby and Reid, 2007; van der Hulst, 2004; van Gorsel, 1994; van Meeteren, 2007). Many farms and floral internet businesses currently use rapid delivery companies such as FedEx Corp. (Memphis, TN), DHL Express (Plantation, FL), and United Parcel Service (Atlanta, GA) to deliver flowers to their customers. However, there is often a lack of proper temperature control when using rapid transit carriers, and flowers can be exposed to high and fluctuating temperatures. This is of particular concern since it is known that high temperatures during transport or storage will reduce vase life and quality of many cut flower species and make ethylene-sensitive species more susceptible to ethylene (Halevy and Mayak, 1973; Nowak and Rudnicki, 1990; Rudnicki, et al., 1991; Sacalis and Seals, 1993).

Previous studies have investigated the effects of a continuous temperature setting during simulated transport or storage on cut flower vase life and quality (Celikel and Reid, 2002, 2005; Cevallos and Reid, 2001; Nell and Leonard, 2005; Zhou et al., 2008). The impact of breaking the cold-chain during transport on cut flower quality has received less attention. van Gorsel and Ravesloot (1994) showed that exposing flowers early in the marketing chain to $20^{\circ} \mathrm{C}$ for $8 \mathrm{~h}$ accelerated flower development of asters (Aster ericoides), chrysanthemum (Dendrathema grandiflorum), dianthus (Dianthus caryophyllus), and baby's breath (Gypsophila paniculata) compared with a continuous exposure of $8{ }^{\circ} \mathrm{C}$. They also showed that when averaged over interruption temperatures $(8,12,16$, 20 , and $24^{\circ} \mathrm{C}$ ), a $\mathrm{l}-\mathrm{d}$ delay in the marketing chain resulted in a $\mathrm{l}-\mathrm{d}$ (aster and baby's breath) to 3 -d (dianthus and chrysanthemum) decrease in vase life. Maxie et al. (1973) exposed 'Improved White Sim' carnation for various lengths of time to typical packing temperatures and found that holding flowers for $24 \mathrm{~h}$ at $20^{\circ} \mathrm{C}$ reduced vase life by $25 \%$ compared with holding at $0{ }^{\circ} \mathrm{C}$. By contrast, a short retail simulation display of $2 \mathrm{~d}$ found no difference in vase life of gerbera when kept at $2,6,10$, and $21^{\circ} \mathrm{C}$ (Nell et al., 2009).

How a rapid mode of transport, with little or no temperature controls, affects fresh cut flower vase life compared with one with better temperature controls, but requiring additional time, has not been investigated. This study evaluated the effect of three commercial transport systems on postharvest quality and vase life of cut alstroemeria, carnation, gerbera, and rose. Flowers

\begin{tabular}{llll}
\hline $\begin{array}{l}\text { Units } \\
\text { To convert U.S. to SI, } \\
\text { multiply by }\end{array}$ & U.S. unit & SI unit & $\begin{array}{l}\text { To convert SI to U.S., } \\
\text { multiply by }\end{array}$ \\
\hline 7.8125 & $\mathrm{fl} \mathrm{oz} / \mathrm{gal}$ & $\mathrm{mL} \cdot \mathrm{L}^{-1}$ & 0.1280 \\
0.3048 & $\mathrm{ft}$ & $\mathrm{m}$ & 3.2808 \\
3.7854 & $\mathrm{gal}$ & $\mathrm{L}$ & 0.2642 \\
2.54 & inch(es) & $\mathrm{cm}$ & 0.3937 \\
0.4536 & $\mathrm{lb}$ & $\mathrm{kg}$ & 2.2046 \\
$\left({ }^{\circ} \mathrm{F}-32\right) \div 1.8$ & ${ }^{\circ} \mathrm{F}$ & ${ }^{\circ} \mathrm{C}$ & $\left(1.8 \times{ }^{\circ} \mathrm{C}\right)+32$
\end{tabular}


were commercially transported (nonsimulated) from farms in Colombia to the United States using a 7-d commercial distribution system with temperature controls and two rapid transport systems, $3 \mathrm{~d}$ or $24 \mathrm{~h}$, with little or no temperature controls, respectively. Flowers were transported on a monthly basis for 1 year.

\section{Materials and methods}

Plant material and general PROCESSING. Five cultivars of cut rose (Freedom, Judy, Pink Engagement, Shocking Versilia, and Vendela), alstroemeria (Diamond, Helios, Mistike, Rebecca, and Sena), carnation (Bolshoi, Cantate, Dusty Catina, Rony, and Rosy Barbara), and gerbera (Carnina, Lorka, Lourdes, Sunglow, and Yardena) were obtained from farms near Bogotá, Colombia (lat. $4^{\circ} 51^{\prime} \mathrm{N}$, long. $74^{\circ} 04^{\prime} \mathrm{W}$, altitude $\approx 2574 \mathrm{~m}$ ). All species were grown under greenhouse conditions using standard cultural practices. Night temperatures averaged $7{ }^{\circ} \mathrm{C}$ and day temperatures reached a high of $20^{\circ} \mathrm{C}$. Day length was consistently $12 \mathrm{~h}$ and maximum daily light level was $\approx 1200$ $\mu \mathrm{mol} \cdot \mathrm{m}^{-2} \cdot \mathrm{s}^{-1}$.

Flowers were harvested at commercial maturity (Reid, 2005), graded for uniform quality, and combined into bunches of multiple stems. Flowers were then recut and hydrated for $30 \mathrm{~min}$ to $1 \mathrm{~h}$ in accordance with commercial practices. Flower bunches were wrapped in sleeves, packed dry in cardboard boxes, and kept overnight in coolers $\left(2\right.$ to $\left.3{ }^{\circ} \mathrm{C}\right)$ at the farm. The next day, flowers were delivered in a non-refrigerated truck to the El Dorado International Airport in Bogotá, Colombia. Flowers were delivered to the University of Florida, Gainesville, using three floral transport systems where flowers arrived within $24 \mathrm{~h}, 3 \mathrm{~d}$, or $7 \mathrm{~d}$.

COMMERCIAL FLORAL TRANSPORT SYSTEMS. The fastest transport system delivered flowers within $24 \mathrm{~h}$ after leaving the farm using FedEx International Priority Delivery System (24 h). Flowers were received by FedEx at the Bogotá airport and flown to Memphis, TN, via one stop in Panama using a cargo airline. Upon arrival in Memphis, flowers were processed through U.S. customs and transported via a FedEx airplane to Jacksonville, FL. Flowers were then driven for $\approx 2 \mathrm{~h}$ to Gainesville, FL, in a non-refrigerated FedEx truck and delivered to the University of Florida. The average total cost per box using this transport system was $\$ 66.10$ (\$5.85/kg plus fuel surcharge).

The second group of flowers arrived in $3 \mathrm{~d}$ using FedEx International Priority Domestic Delivery System (3d). Flowers were received by FedEx at the Bogotá airport and flown to Miami, FL, using a cargo airline. Flowers were kept at a Miami importer for $\approx 1.5 \mathrm{~d}$ under refrigerated conditions. Flowers were then transported in a commercial FedEx truck for 13 to $14 \mathrm{~h}$ until arrival in Memphis, TN. Flowers were processed through U.S. customs and flown on a FedEx airplane to Jacksonville, FL, and delivered to the University of Florida as outlined earlier. The average total cost per box using the 3 -d transport system was $\$ 38.42(\$ 3.40 / \mathrm{kg}$ plus fuel surcharge).

The third transport system $(7 \mathrm{~d})$ used the most widely practiced mode of transporting flowers from Colombia to the United States when using Miami as a distribution point to destinations throughout the United States. Flowers were flown from Colombia to Miami, FL, using a cargo airline. Upon arrival in Miami, flowers were processed through U.S. customs and transported via a non-refrigerated truck to a local floral importer where they were kept for $\approx 1.5 \mathrm{~d}$ under refrigerated conditions. Flowers were then delivered within $30 \mathrm{~min}$ by the importer to a floral trucking company in Miami, which then transported the flowers in a refrigerated truck to a floral distributer (East Palatka, FL) within several hours. Flowers were kept in boxes under refrigerated conditions at the distributer for 2 to $2.5 \mathrm{~d}$. Flowers were then placed on a refrigerated floral transport truck for $\approx 1.5 \mathrm{~h}$ until final delivery to the University of Florida. It took a total of $7 \mathrm{~d}$ to arrive in Gainesville, FL. The average total cost per box using the 7-d transport system was $\$ 22.04$ (fuel inclusive).

A total of 12 individual shipments per transport system were evaluated on a monthly basis from Feb. 2007 to Jan. 2008. The same farms, cultivars, transport systems, importer, trucking companies, and handling processes were provided for each shipment to obtain as much consistency as possible. A total of four boxes of roses were sent for each of the 12 monthly shipments per transport system with one bunch ( 25 stems per bunch) per cultivar per box. A total of three extra rose bunches were included in each box to fill the box (eight bunches per box). For the alstroemeria, carnation, and gerbera, four boxes were also sent per transport system per shipment. Each of these boxes contained one bunch of each cultivar and species (10 stems per bunch for alstroemerias and carnations and five stems per bunch for gerberas). Roses were not received in the 24-h transport system in the July shipment and in the 7 - $d$ transport system in the September shipment because of lack of availability.

Temperature data loggers were placed in each shipping box (Hobo Pendant UA-001-64; Onset Computer Corp., Bourne, MA) for every shipment. Transport temperatures were averaged over each season by grouping the following months together: winter = December, January, February; spring = March, April, May; summer = June, July, August; and fall = September, October, November. The transport temperatures for roses are presented since nearly identical temperatures were found for the other floral species given that all species were transported together from Bogotá.

General processing. Flowers were processed immediately upon arrival. Stems free of disease or damage were selected randomly from each of the four bunches for each species and cultivar. The lower leaves were removed and stems were cut with sterilized hand pruners to a length of $42 \mathrm{~cm}$. In cases where gerbera stems were less than $42 \mathrm{~cm}, 2 \mathrm{~cm}$ was cut off the lower part of the stem. Flowers were then placed into clean, sterilized plastic buckets containing $4 \mathrm{~L}$ of a commercial hydration solution mixed with tap water at $10 \mathrm{~mL} \cdot \mathrm{L}^{-1}$ (Chrysal Clear Professional Processing Solution No. 2; Chrysal International, Naarden, The Netherlands) for $3 \mathrm{~d}$ at $3{ }^{\circ} \mathrm{C}$ in the dark to simulate wholesale or retail conditions. Each species was hydrated in separate buckets.

After hydration, stems were cut to $40 \mathrm{~cm}$ with sterilized hand pruners and placed into vases containing $1 \mathrm{~L}$ of a commercial flower food mixed with tap water at $15 \mathrm{~mL} \cdot \mathrm{L}^{-1}$ (Chrysal Clear Professional Vase Solution No. 3; Chrysal International). Each vase contained a total of 10 stems (one cultivar per vase) except for gerbera which had five stems per vase (one cultivar per vase). Flowers were maintained until end of vase life in a postharvest 
evaluation room maintained at $21{ }^{\circ} \mathrm{C}$ and $50 \% \pm 5 \%$ relative humidity. Overhead cool white fluorescent bulbs (Sylvania, Danvers, MA) provided $10 \mu \mathrm{mol} \cdot \mathrm{m}^{-2} \cdot \mathrm{s}^{-1}$ of light at flower height for $12 \mathrm{~h} \cdot \mathrm{d}^{-1}$.

Postharvest assessments. Vase life of each individual flower stem was recorded from the time placed into vase until wilting and/or discoloration of the flower (rose and gerbera) or wilting of $50 \%$ of the open florets (alstroemeria and carnation) occurred. Flower opening stage was recorded initially when placed into vases and every $3 \mathrm{~d}$ thereafter using the following rating score: $1=$ outer petals tightly wrapped around the bud; 2 = outer petals starting to reflex from the bud; 3 = outer petals reflexed about $135^{\circ}$ to the stem; $4=$ outer petals reflexed about $115^{\circ}$ to the stem; and $5=$ outer petals reflexed at $90^{\circ}$ to the stem (modified from Kuiper et al., 1996).

EXPERIMENT DESIGN AND ANALYSIS. All experiments were arranged in a randomized complete block design within the postharvest evaluation room. The evaluation of each transport system was repeated 12 times on a monthly basis over the course of a year (Feb. 2007 to Jan. 2008). A total of 40 stems per cultivar of alstroemeria, carnation, and roses (four vases with 10 stems per vase) and 20 stems per cultivar of gerbera (four vases with five stems per vase) were evaluated for each transport system for each monthly shipment. Each species was subjected to analysis of variance using the generalized linear model procedure of SAS (version 9.1; SAS Institute, Cary, NC). Tukey's test was used to determine significant differences among the three transport systems within each floral species at $P=0.05$.

\section{Results}

Temperature DURING TransPORT. Each transport system exhibited a distinct temperature pattern throughout the year (Fig. IA-C). However, the range in temperatures varied among the seasons. The $24-\mathrm{h}$ transport flowers were never cooled during transit and showed a steady increase in temperatures from the time flowers left the farm until arrival (Fig. 1A). For flowers in this transit system, temperature was $\approx 4^{\circ} \mathrm{C}$ higher in the first 2 to $2.5 \mathrm{~h}$ in transit during the summer months compared with the spring, fall, and winter months.
Temperatures were also consistently higher by several degrees in the summer months during the last $6 \mathrm{~h}$ in transit from Memphis, TN, until arrival, compared with the other times of the year. The 24-h transport system had an average temperature of $27^{\circ} \mathrm{C}$ upon arrival in the summer, $24{ }^{\circ} \mathrm{C}$ upon arrival in the fall, $22^{\circ} \mathrm{C}$ upon arrival in the spring, and $17^{\circ} \mathrm{C}$ upon arrival in the winter.

The 3-d transport system had a steady increase in temperature during transport to Miami, FL, in the spring, summer, and fall months (Fig. 1B). By contrast, the winter season showed an initial increase in temperature then a decrease in temperature that was 2 to $9{ }^{\circ} \mathrm{C}$ lower than the other seasons. For the 3-d system, temperatures in the summer months averaged several degrees higher during transport to and upon arrival in Miami compared with the other seasons (Fig. 1B). Temperatures then slowly, but steadily, declined while kept at the importer in Miami during the next $1.5 \mathrm{~d}$ for all shipments except the spring shipments, where temperatures remained fairly constant and several degrees higher in comparison with the other seasons (Fig. 1B). Temperatures then increased over the next 12 to $13 \mathrm{~h}$ during truck transport to Memphis. During truck transport and upon arrival in Memphis, temperatures were $\approx 5$ to $8^{\circ} \mathrm{C}$ lower in the fall and winter shipments compared with the spring and summer shipments. Once in Memphis, temperatures continued to increase steadily for all seasons over the next several hours during air and truck transport until arrival in Gainesville, FL. Summer temperatures were substantially higher during the final 6 to 8 h of transit compared with the other seasons. The average temperature upon arrival after $3 \mathrm{~d}$ of transit was $24^{\circ} \mathrm{C}$ in the summer, $18^{\circ} \mathrm{C}$ in the spring and fall, and $12^{\circ} \mathrm{C}$ during the winter shipments.

In the first $3.5 \mathrm{~d}$ during the $7-\mathrm{d}$ transport, temperatures fluctuated because of the numerous steps in flower handling (Fig. 1C). Temperatures steadily increased once they left the farm and during air transit to Miami. Temperatures were up to $6^{\circ} \mathrm{C}$ higher in the summer months during transit to and upon arrival in Miami compared with the other seasons. Temperatures then steadily decreased several degrees while kept at the floral importer in Miami (Fig. 1C). Temperatures increased once again when leaving the importer until on the first floral transport truck and then steadily declined thereafter. During the final 2 to $2.5 \mathrm{~d}$ in the 7 - $\mathrm{d}$ transport system, flowers were maintained at 5 to $7^{\circ} \mathrm{C}$ until arrival.

VASE LIFE AND QUALITY. Alstroemeria lasted nearly 2 weeks or longer regardless of transport system or time of year (Fig. 2A). In 10 of the 12 shipments, alstroemeria flowers lasted significantly longer in the rapid transport systems compared with a 7 -d transport (Fig. 2A). Alstroemeria transported in the 24-h system lasted from 0.8 to $4.6 \mathrm{~d}$ longer than those in the 3 - and 7 -d transport systems, respectively. There was no difference in alstroemeria vase life observed among the transport systems in the February trial. The greatest reduction in alstroemeria vase life was observed when transported using the 7-d transport system during the months of August and September. The alstroemeria cultivars responded similarly to the transport systems, in which vase life (averaged over shipments) increased from $3.2 \%(0.5 \mathrm{~d})$ for 'Rebecca' to $16.7 \%(2.7 \mathrm{~d})$ for 'Diamond' as transport time decreased (data not shown).

There were no differences observed in alstroemeria flower opening among the cultivars, the transport systems, or among the monthly shipments after a few days in the postharvest evaluation room (data not shown). Most flowers opened within 3 to $5 \mathrm{~d}$ after placement into vases. The 7-d transported flowers, however, generally had more open flowers initially upon placement into vases compared with the rapid transport systems.

In 7 of the 12 shipments, carnation vase life was significantly greater (2.4 to $4.1 \mathrm{~d})$ when flowers were transported using the rapid transport systems compared with the 7-d system (Fig. 2B). In 11 of the 12 shipments, there were no differences in carnation vase life between the 3 - $\mathrm{d}$ system and the 24-h and 7-d transport systems. Carnation flowers lasted longer in the February shipment and lower in the November shipment. There was no difference in carnation vase life among the transport systems in the June, July, September, November, and January shipments. As transport time increased, vase life (averaged over shipments) of the carnation cultivars decreased from $0.9 \mathrm{~d}(3.6 \%)$ for 'Rosy Barbara' to 2.3 d $(8.8 \%)$ for 'Dusty Catina', except 

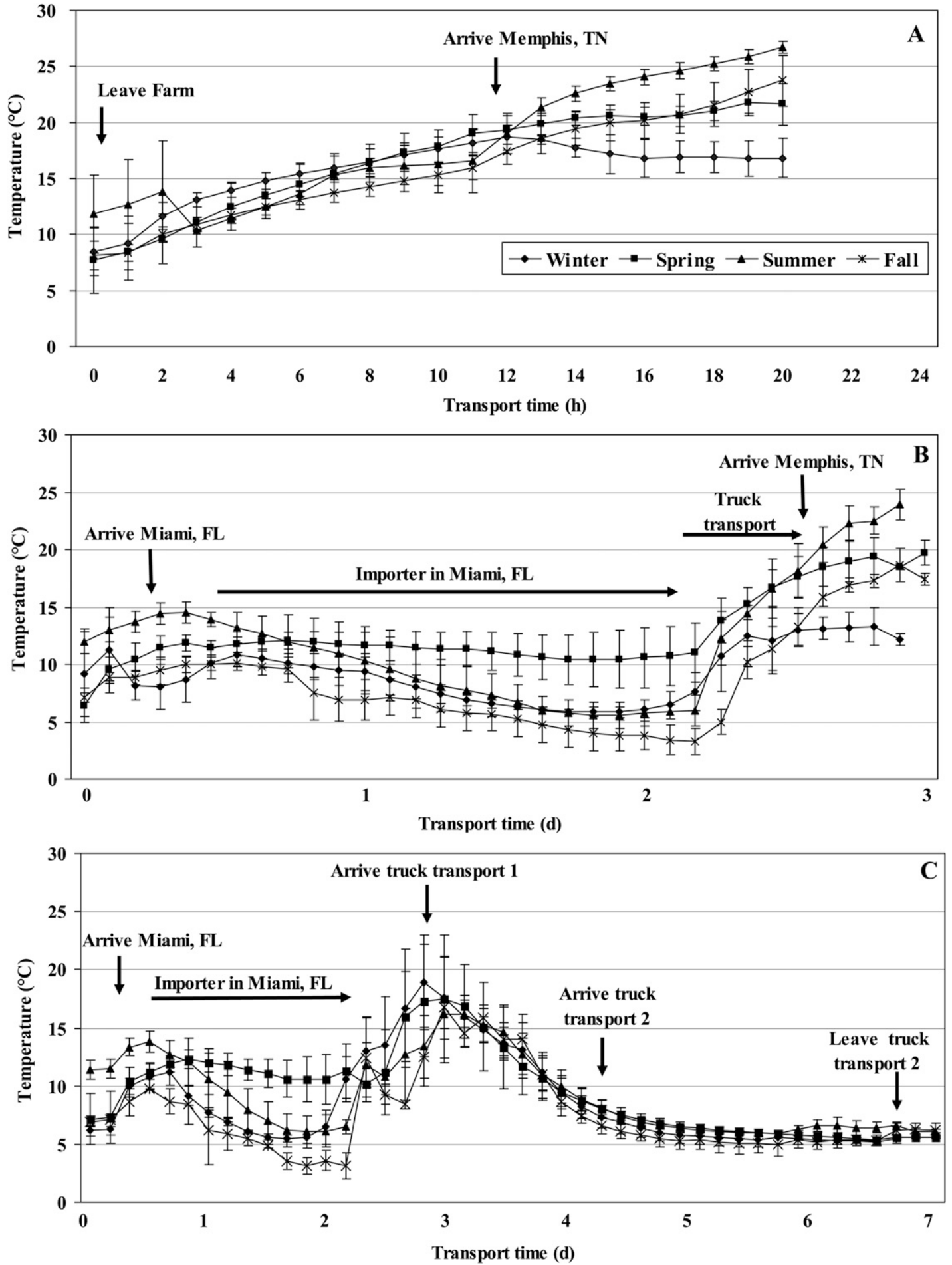

Fig. 1. Temperature recordings during transport of cut roses from Colombia, South America, to the United States using three transport systems: (A) 24-h system, where flowers were transported via a cargo plane from Bogotá to Memphis, TN, flown in a FedEx Corp. plane to Jacksonville, FL, and then driven for $2 \mathrm{~h}$ to Gainesville, FL; (B) 3-d system, where flowers were transported via cargo plane from Bogotá to Miami, FL, kept at a Miami importer for $1.5 \mathrm{~d}$, driven to Memphis, flown to Jacksonville, and then driven for $2 \mathrm{~h}$ to Gainesville; or (C) 7-d system, where flowers were transported via cargo plane from Bogotá to Miami, kept at a Miami importer for $1.5 \mathrm{~d}$, driven to a wholesaler in East Palatka, FL (truck transport 1), and then driven to Gainesville (truck transport 2). Results are grouped by season (winter = December, January, February; spring = March, April, May; summer = June, July, August; and fall = September, October, November $)$. Data are means \pm SE; $\left(1.8 \times{ }^{\circ} \mathrm{C}\right)+32={ }^{\circ} \mathrm{F}$.

for 'Cantate', where no differences were observed (data not shown).

Carnation flowers opened for all cultivars in all transport systems after
3 to $5 \mathrm{~d}$ in postharvest conditions (data not shown). The 7-d transported flowers, however, generally had more open flowers upon placement into vases compared with the rapid transport systems.

In 5 of the 12 shipments, gerbera vase life was greater when flowers 

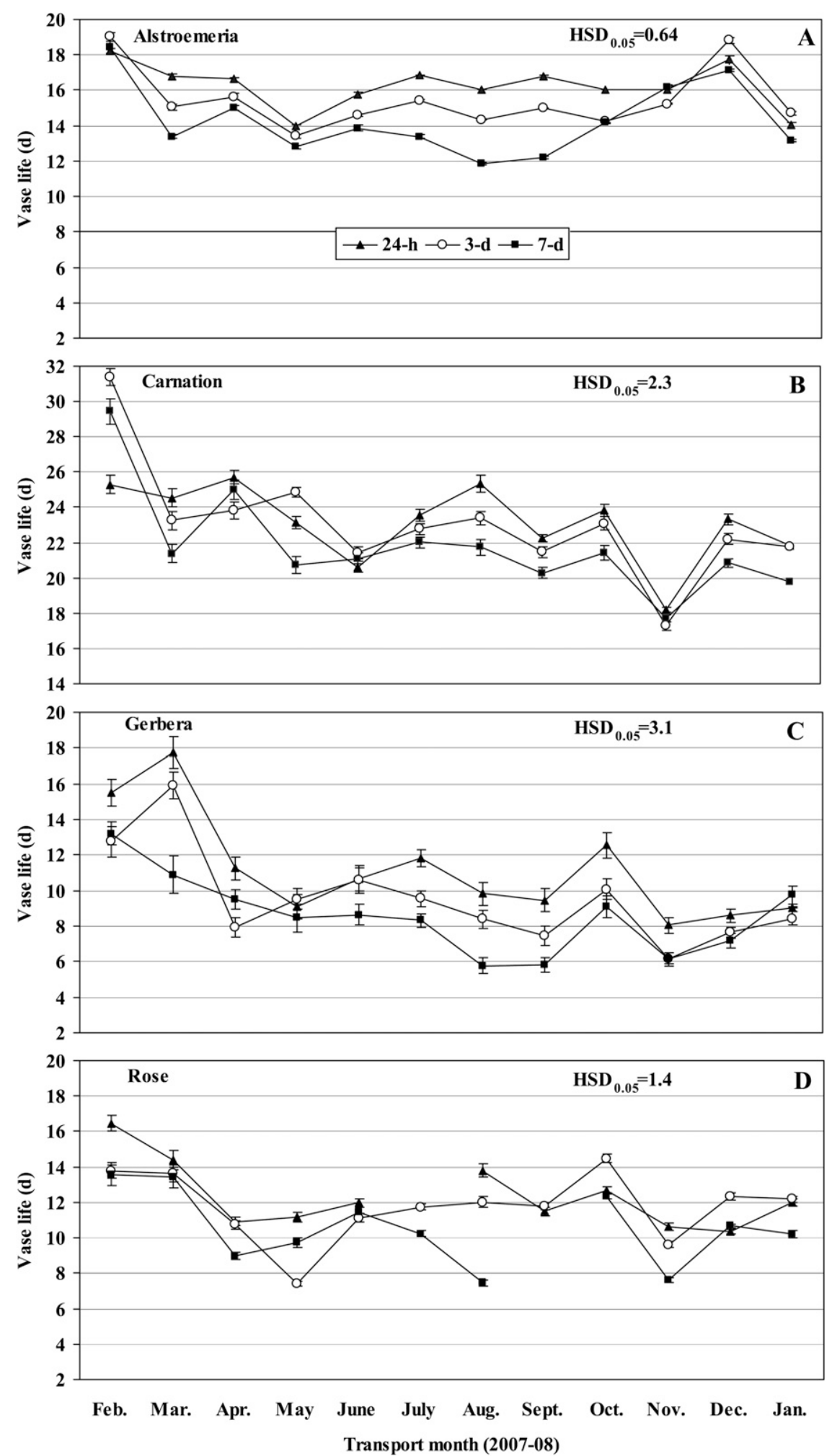

Fig. 2. Vase life of cut (A) alstroemeria, (B) carnation, (C) gerbera, and (D) rose after transport from Colombia, South America, to the United States using 24-h, 3 -d, or 7-d commercial transport systems. Data are means \pm SE. Tukey's honestly significant difference (HSD) test at $P=0.05\left(\mathrm{HSD}_{0.05}\right)$ was used to test differences among treatment means. The probability value from analysis of variance for the transport month $\times$ transport system interaction was $<0.0001$ for all species.

were transported using the 24 -h transport system compared with the 7-d system (Fig. 2C). Gerbera vase life significantly increased 3.4 to $6.9 \mathrm{~d}$ using the 24-h transport compared with the 7 -d transport system only during the months of March, July, August, September, and October. No difference in gerbera vase life was observed between the 3 - $d$ transport and the 24-h and 7-d systems excluding the shipments in April and March, respectively. The gerbera cultivars Lourdes, Sunglow, and Yardena were especially sensitive to the 7-d transport system, as vase life (averaged over shipments) decreased $3.4(44.7 \%), 3.8$ (27.1\%), and $6.2 \mathrm{~d}(34.6 \%)$, respectively, compared with flowers transported in the 24-h system (data not shown).

For $82 \%$ of the rose shipments, the rapid transport systems had a significantly longer vase life ( 1.4 to $6.3 \mathrm{~d}$ ) compared with the 7 - $d$ transport system (Fig. 2D). The largest reduction in rose vase life when using the 7-d transport system occurred in August, in which vase life was reduced $38 \%$ and $46 \%$ compared with the $3-\mathrm{d}$ and 24-h transport systems, respectively (Fig. 2D). No differences in rose vase life occurred among the transport systems in the March and June shipments. Although the rose cultivars varied in their lasting qualities, all cultivars except 'Vendela' had a decrease in vase life (averaged over shipments) ranging from $0.7 \mathrm{~d}(5.6 \%)$ for 'Shocking Versilia' to $2.1 \mathrm{~d}(17.1 \%)$ for 'Freedom' as transport time increased (data not shown).

Flower opening varied among the rose cultivars and but only the cultivars Freedom and Shocking Versilia were affected by the transport systems (Fig. 3). For these cultivars, the 7-d transport system had a reduction in flower opening compared with the rapid transport systems.

\section{Discussion}

This study shows that for the majority of shipments, transporting fresh, non-stored flowers within $24 \mathrm{~h}$ to $3 \mathrm{~d}$ results in a longer vase life compared with a 7 -d transport. Other studies have also shown that increased storage duration can result in a decrease in vase life and quality of cut flowers where the magnitude of the response depends on the floral species, cultivar, length of storage, and temperature (Celikel and Reid, 2002; Leonard et al., 2001; Nell et al., 2009; Waithaka et al., 2001). As storage time of 'Classy' rose increased from 3 to $12 \mathrm{~d}$, vase life was found to decrease $8 \%$ and $38 \%$, respectively, compared with non-stored flowers (Leonard et al., 2001). A short 


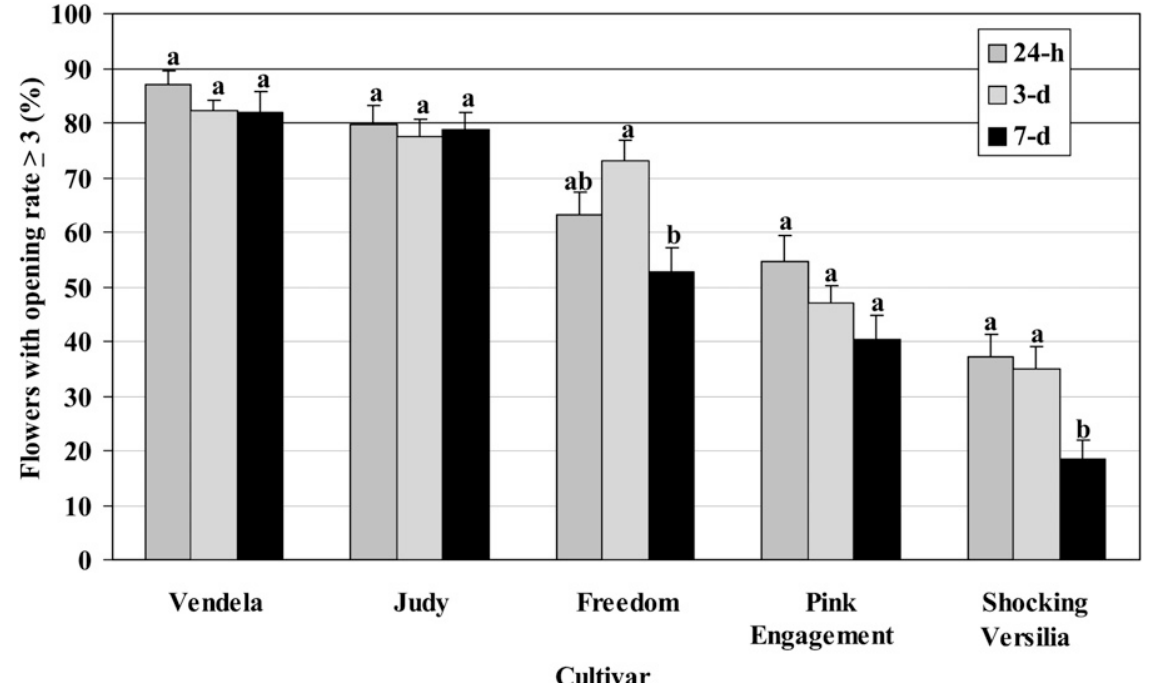

Fig. 3. The percentage of cut rose flowers that opened to a flower opening stage of $\geq 3$ (outer petals reflexed about $135^{\circ}$ to the stem; halfway open) after $9 \mathrm{~d}$ in postharvest after transport from Colombia, South America, to the United States using 24-h, 3-d, or 7-d commercial transport systems. Means \pm SE within each cultivar followed by different letters are significantly different at $P=0.05$ using Tukey's honestly significant difference test.

retail simulation display of $2 \mathrm{~d}$ found no difference in vase life of gerbera when kept at $2,6,10$, and $21^{\circ} \mathrm{C}$ (Nell et al., 2009). However, when kept for $4 \mathrm{~d}$, gerbera vase life decreased from $13 \%$ at $2{ }^{\circ} \mathrm{C}$ to $35 \%$ at $21{ }^{\circ} \mathrm{C}$ when compared with flowers kept for $2 \mathrm{~d}$ at these same temperatures.

The temperature recordings from the transport systems (Fig. IA-C) show that the flowers were subjected to fluctuating and at times substantially higher temperatures than are recommended for most cut flowers to promote maximum vase life and quality (Halevy and Mayak, 1981; Nowak and Rudnicki, 1990; Sacalis and Seals, 1993). As temperatures increase, an increase in respiration rate and sensitivity to ethylene, moisture loss, and disease susceptibility occurs (Cevallos and Reid, 2000; Maxie et al., 1973; Salinas, et al., 1989; van Doorn, 1997). The respiration rate of cut gerbera (Celikel and Reid, 2002) and cut rose flowers (Celikel and Reid, 2005) was found to increase exponentially with increasing temperature. These flowers respired three times faster at $10{ }^{\circ} \mathrm{C}$ compared with $0{ }^{\circ} \mathrm{C}$. Consequently, vase life was reduced $38 \%$ for gerbera and $40 \%$ for roses after $5 \mathrm{~d}$ at $10{ }^{\circ} \mathrm{C}$ compared with $0{ }^{\circ} \mathrm{C}$.

Our results demonstrate that the cut flower species tested are able to tolerate high and fluctuating temperatures for short periods without substantially affecting vase life and quality. Under the conditions encountered in this study, most flowers were probably able to maintain their metabolism at a rate that did not decrease carbohydrate reserves or alter the moisture content to a level that would significantly impact vase life (van Doorn, 1997). In our study, flowers in the 24-h transport system were subjected to temperatures at or above $8^{\circ} \mathrm{C}$ for $\approx 20 \mathrm{~h}$ with at least $10 \mathrm{~h}$ of that time above $15{ }^{\circ} \mathrm{C}$ or higher and still had very acceptable vase life and quality. Although there were no non-shipped controls to compare the relative loss in vase life because of transport, flowers were nevertheless relatively long-lasting under the conditions tested. Similar results were demonstrated in a simulation model on cut flowers where the effects of specific temperatures in hypothetical distribution chains were analyzed. Those results showed that in short local distribution chains, the short duration of the chain was more important than its temperature (van Meeteren, 2007).

A concern with subjecting flowers to fluctuating temperatures is the potential of condensation of water as flowers are transferred from cold to warm or warm to cold temperatures, making them more susceptible to common diseases such as gray mold
(Botrytis cinerea) (Salinas, et al., 1989; van Kan, 2005). In this study, however, gray mold rarely developed in any of the floral species or transport systems. Presumably, the application of fungicides before transport was effective in controlling the incidence of diseases.

Another major concern when transporting flowers at high temperatures is the greater susceptibility to ethylene injury on sensitive species. To combat this issue when using these transport systems, sensitive flowers should be treated with antiethylene agents such as silver thiosulphate or l-methylcyclopropene (EthylBloc ${ }^{\mathrm{TM}}$; Floralife, Walterboro, SC) (Nowak and Rudnicki, 1990; Macnish et al., 2010; Serek et al., 1995).

Despite the variation in transport temperatures during the year, there was no consistent trend in the vase life among the floral species. Periods of reduced vase life did not necessarily occur in the summer months when higher temperatures were encountered, especially when using the $24-\mathrm{h}$ and 3-d transport systems (Fig. 1A-C). For instance, carnation vase life was lowest in the November shipment. Interestingly, alstroemeria, rose, and gerbera did exhibit a greater reduction in vase life during the August and September shipments but it occurred in the 7-d transport system which was not exposed to as high a temperature as the 24-h and 3-d systems.

Although temperature variations existed during transport throughout the year in this study, it is difficult to ascertain that these transport systems were solely responsible for the variation in vase life throughout the year. Each shipment was subjected to similar, but not exact, environmental and production conditions at the farm, po- $^{-}$ tentially explaining some of the variation among shipments. It is well known that preharvest conditions and seasonal factors such as light, temperature, and carbohydrate status can influence the vase life and quality of cut carnations (Celikel and Karaçalý, 1995; Paul et al., 1977), gerberas (van Doorn et al., 1994), and roses (Moe, 1975; Pompodakis et al., 2005; Slootweg et al., 2001; van Doorn et al., 1991). In the present study, using the same farms, cultivars, transport systems, importer, trucking companies, and handling processes provided as much consistency as possible, but variation in preharvest factors needs to be 
considered when evaluating these transport systems.

Keeping flowers at a constant low temperature during the entire transportation of flowers on a local or global scale is extremely difficult and has yet to be accomplished (Reid, 2001; Reid and Jiang, 2005). The impact of breaking the cold-chain one or more times during transport, the duration of the break, and the temperature of the break before vase life is significantly affected has not been well studied on cut flowers. This study was not designed to determine these limits, rather to document temperature conditions during various commercial transport systems and the resultant vase life and quality. Yet, our data show that cut flowers can withstand some temperature interruptions during transit and still have good quality and vase life.

In conclusion, this study demonstrated that the transport systems used to transport flowers from Colombia to the United States expose flowers to fluctuating and, at times, substantially higher temperatures than are recommended for most cut flowers. For the majority of shipments, flowers transported within $24 \mathrm{~h}$ to $3 \mathrm{~d}$ had increased vase life compared with those transported for $7 \mathrm{~d}$. To promote quality when using these less than optimal transport systems, flowers should be pretreated to protect against disease and ethylene exposure. Flowers should not be stored and need to be properly handled and hydrated using commercial floral solutions before and after transport.

\section{Literature cited}

Celikel, F.G. and Y. Karaçalý. 1995. Effect of preharvest factors on flower quality and longevity of cut carnations (Dianthus caryophyllus L.). Acta Hort. 405:156163.

Celikel, F.G. and M.S. Reid. 2002. Storage temperature affects the quality of cut flowers from the Asteraceae. HortScience $37: 148-150$

Celikel, F.G. and M.S. Reid. 2005. Temperature and postharvest performance of rose (Rosa hybrida L. 'First Red') and gypsophila (Gypsophila paniculata L. 'Bristol Fairy') flowers. Acta Hort. 682:1789-1794.

Cevallos, J.C. and M.S. Reid. 2000. Effects of temperature on the respiration and vase life of Narcissus flowers. Acta Hort. 517:335-341.
Cevallos, J.C. and M.S. Reid. 2001. Effect of dry and wet storage at different temperatures on the vase life of cut flowers. HortTechnology 11:199-202.

Halevy, A.H. and S. Mayak. 1973. Transport and conditioning of cut flowers. Acta Hort. 43:291-306.

Halevy, A.H. and S. Mayak. 1981. Senescence and postharvest physiology of cut flowers. Part 2. Hort. Rev. 3:59-143.

Jerardo, A. 2007. Floriculture and nursery crops yearbook. Market Trade Econ. Div., Econ. Res. Serv., U.S. Dept. Agr., Sept. 2007, FLO-2007.

Kuiper, D., H.S. van Reenen, and S.A. Ribot. 1996. Characterisation of flower bud opening in roses; a comparison of Madelon and Sonia roses. Postharvest Biol. Technol. 9(1):75-86.

Leonard, R.T., T.A. Nell, A. Suzuki, J.E. Barrett, and D.G. Clark. 2001. Evaluation of long term transport of Colombian grown cut roses. Acta Hort. 543:293297.

Macnish, A.J., R.T. Leonard, A.M. Borda, and T.A. Nell. 2010. Genotypic variation in the postharvest performance and ethylene sensitivity of cut rose flowers. HortScience 45:790-796.

Maxie, E.C., D.S. Farnham, F.G. Mitchell, N.F. Sommer, R.A. Parsons, R.G. Snyder, and H.L. Rae. 1973. Temperature and ethylene effects on cut flowers of carnations (Dianthus caryophyllus). J. Amer. Soc. Hort. Sci. 98(6):568-572.

Moe, R. 1975. The effect of growing temperature on keeping quality of cut roses. Acta Hort. 41:77-92.

Nell, T.A. and R.T. Leonard. 2005. The effect of storage temperatures on Colombian grown cut rose varieties. Acta Hort. 669:337-342.

Nell, T.A., R.T. Leonard, and A.M. Alexander. 2009. The effects of retail display conditions on postharvest performance of cut Gerbera jamesonii. Acta Hort. 847:5l-58.

Nowak, J. and R.M. Rudnicki. 1990. Postharvest handling and storage of cut flowers, florist greens, and potted plants. Timber Press Inc., Portland, OR.

Paul, J.L., A.M. Kofranek, and J. Kubota. 1977. The influence of season on cut flower conditioning response in 'White Sim' carnations. Acta Hort. 40:177-186.

Pompodakis, N.E., L.A. Terry, D.C. Joyce, D.E. Lydakis, and M.D. Papadimitriou. 2005. Effect of seasonal variation and storage temperature on leaf chlorophyll fluorescence and vase life of cut roses. Postharvest Biol. Technol. 36(1):1-8.
Reid, M.S. 2001. Advances in shipping and handling of ornamentals. Acta Hort. 543:277-284

Reid, M.S. 2005. Cut flowers and greens. In: K. Gross, C. Wang, and M. Saltveit (eds.). The commercial storage of fruits, vegetables, and florist and nursery stocks. U.S. Dept. Agr. Hdbk. No. 66. 20 June 2011. <http://www.ba.ars.usda.gov/ hb66/contents.html>.

Reid, M.S. and C.Z. Jiang. 2005. New strategies in transportation for floricultural crops. Acta Hort. 682:16671673.

Rudnicki, R.M., J. Nowak, and D.M. Goszczynska. 1991. Cold storage and transportation conditions for cut flowers cuttings and potted plants. Acta Hort. 298:225-236.

Sacalis, J.N. and J.L. Seals. 1993. Cut flowers: Prolonging freshness: Postproduction care and handling. Ball Publ., Batavia, IL.

Salinas, J., D.C.M. Glandorf, F.D. Picavet, and K. Verhoeff. 1989. Effects of temperature, relative humidity and age of conidia on the incidence of spotting on gerbera flowers caused by Botrytis cinerea. Neth. J. Plant Pathol. 95(1):5164.

Serek, M., E.C. Sisler, and M.S. Reid. 1995. Effects of 1-MCP on the vase life and ethylene response of cut flowers. Plant Growth Regulat. 16(1):93-97.

Slootweg, G., M.A. ten Hoope, and A. de Gelder. 2001. Seasonal changes in vase life, transpiration and leaf drying of cut roses. Acta Hort. 543:337-342.

Staby, G. and M. Reid. 2007. Improving the cold chain for cut flowers and potted plants. White Paper II. 18 June 2011. <http://www.wffsa.org/pdf/2007/ WhitePaperiiFinalcorrectedApr2007.pdfs.

van der Hulst, J. 2004. Cool chain management for cut flowers. FlowerTECH 7(6):49-51.

van Doorn, W.G. 1997. Water relations of cut flowers. Hort. Rev. 18:1-85.

van Doorn, W.G., G. Groenewegen, P.A. van de Pol, and C.E.M. Berkholst. 1991. Effects of carbohydrate and water status on flower opening of cut Madelon roses. Postharvest Biol. Technol. l(1): 47-57.

van Doorn, W.G., M. Veken, and M.L. Bakker. 1994. Effect of dry storage on scape bending in cut Gerbera jamesonii flowers. Postharvest Biol. Technol. 4(3): 261-269.

van Gorsel, R. 1994. Postharvest technology of imported and trans-shipped tropical 


\section{Research Reports}

floricultural commodities. HortScience 29:979-981.

van Gorsel, R. and M. Ravesloot. 1994. Short interruptions of the cold chain reduce the vase life of Aster ericoides, chrysanthemum, dianthus, and gypsophila cut flowers. HortScience 29(5):554. van Kan, J.A.L. 2005. Infection strategies of Botrytis cinerea. Acta Hort. 669:77-89

van Meeteren, U. 2007. Why do we treat flowers the way we do? A system analysis approach of the cut flower postharvest chain. Acta Hort. 755:61-73.

Waithaka, K., M.S. Reid, and L.L. Dodge. 2001. Cold storage and flower keeping quality of cut tuberose (Polianthes tuberose L.). J. Hort. Sci. Biotechnol. 76(3):271275 .

Zhou, L., P. Jia, W. Guo, L. Wang, and L. Dong. 2008. Effect of different storage temperature on postharvest quality of cut flowers of tree peony 'Luo Yang Hong'. Acta Hort. 768:455-461. 